\title{
The Nuanced Approaches in Destination Branding and Promotion of Film-Induced Tourism: A Mixed Method Inquiry Based in Puducherry
}

Anu Chandran R C *

\begin{abstract}
Puducherry (formerly Pondicherry) is a scintillating tourism destination in south India. Puducherry is a multiUSP destination with a quiet charm that envelops the tourists. Its French heritage is apparent across the length and breadth of the Union Territory. Renowned world over, as the 'French Riviera of the East', Puducherry sparkles with rich and illustrious culture and history. The spiritual aura, which is a hallmark feature of the destination, rings in the tourists. The tourism industry in Puducherry is booming with both domestic and foreign tourists' influx showing a remarkable upward trend in the recent years. This destination dots a prominent place in the tourism map of India owing to the outstanding heritage monuments and cultural manifests. The landscape of Puducherry is quite exciting as it is dotted with exotic beaches and serene resorts. Film tourism is a neo-tourism form which has gained increased attention in Puducherry's tourism industry. The study of film tourism is relatively new in tourism research. The present paper deals with the film tourism potential of Puducherry, that is in the reckoning to be a dynamic factor in the branding
\end{abstract}

\footnotetext{
Assistant Professor, Department of Tourism Studies, Pondicherry University, Kalapet, Puducherry-605014, India; anoos_ind@yahoo.co.in
} 
of the destination. The aesthetically designed buildings and structures coupled with the stunning beaches and ravines make Puducherry an ideal film-shooting location. The popularity of the destination is catapulted to a great extent, thanks to the numerous incredible movies, advertisements, and documentaries shot in the amazing locales of Puducherry. The need of the hour with regard to film tourism in Puducherry is the orchestration of vibrant discussions and deliberations on the merits and shortcomings of film tourism as a tool for, or component of destination branding. There are genuine concerns with respect to mass tourism, carrying capacity, hostacceptance and other aspects. This study examines how films taken in Puducherry have affected the image of the destination. Furthermore, the influence of tourism spots on the movies shot in Puducherry is also dealt within this paper. Focus Group Interviews and Delphi - Technique are employed to bring to light the opportunities and challenges associated with film tourism in Puducherry. A survey was conducted among select group of domestic tourists to ascertain the influence of films shot in Puducherry on their visits. Content analysis is resorted to for drawing inferences. The purpose of this work is to gather insights on how attributes and authenticity linked to film tourism influence tourists and destination branding.

Keywords: Destination Puducherry, Branding, Film Tourism, Marketing Strategies, Image

\section{Introduction}

Film tourism, as a special interest or niche form of tourism has gained immense currency in the tourism industry of destinations endowed with enchanting locales and vibrant cultural manifestations. It implies relishing the offerings and also the 'sense of place' captured in the frames, which essentially stimulate the viewers to such an extent that they desire to see it or be partakers of the experiences for real. The success of film tourism depends on how the unique habitats are portrayed. Of course, the visuals also play a key role in captivating the viewers and translating them into actual tourists. The Bollywood blockbuster 'Zindagi Na Milegi 
Dubara', shot widely in Spain glorifying its cultural expressions including 'La Tomatina' festival, lured many tourists from other parts of the world to experience the specialties that were depicted in the movie. Consequently, with the identification that films can catapult tourist arrivals given the popularity of the medium, tourist destinations worldwide are purposefully and actively using them as a powerful promotional tool. Thus, movie-induced tourism is becoming trendy, and is extensively used for marketing tourist destinations. The fact of the matter is that, films can exert a strong influence on the decision-making capacities of potential tourists. Evans (1997) defines film tourism as: "Tourist visits to a destination or attraction as a result of the destination being featured on television, video or the cinema screen."

Globally, tourism is witnessing a paradigm shift. Experiential holidays are the order of the day. The modern day tourists are not satisfied with merely engaging in sightseeing or being passive visitors. They want to get totally involved with the proceedings dished out by the Destination Management Organizations (DMO's). Tourism as a sunrise industry is evolving continuously and the forecasts of UNWTO's World Tourism Barometer and WTTC's Tourism Satellite Accounting (TSA) with respect to world tourist arrivals and tourism activities are quite promising. As per the projections of the tourism organizations, world tourist arrivals is expected to touch 1.5 billion in 2015 growing at an annual rate of $4.5 \%$. Realizing the benefits that tourism can bring about in a destination, countries across the globe have regarded it as an 'agent of change'. There is stiff competition between tourism destinations to obtain the optimum share of tourist arrivals. Enticing tourists to a destination definitely calls for a great deal of creativity owing to intense competition. The key questions destination marketers raise for themselves for attaining productive outcomes are: Who are the tourists? What do they want? How the distinct attractions and resources can be communicated or showcased effectively? Post identification of the USP's of a tourism destination, which lends a unique and distinct image; the concern of developers is how they can be transmitted with profound impact. Film-induced tourism is regarded as a different approach, yet, streaming to promote the destinations. In that sense, film makers who portray the charms of destinations in a spectacular light can be called 'dream sellers'. The 
silver screen reminds the viewers that these places are worth the watch and they get etched in the memories to be transformed as a desire to travel.

Film tourism as a growing phenomenon is fuelled by two factors. Firstly, the entertainment industry is advancing at a fast pace and its reflections are apparent in film tourism development. The promising rise in world tourism and travel is the second one. Appealing to wide and diverse markets, film tourism offers 'something for everyone' and tourism organizations world over exploits films as springboards for their marketing campaigns. Both tourism and cinema are big industries. Films are donning the role of 'virtual holiday brochures'. At the same time, innovative ventures at tourism destinations help the film industry to a great deal. Thus, it turns out to be a win-win situation for cinema and tourism.

\section{A Bird's Eye View on Film Tourism}

Films are turning out to be rich marketing tools to 'pull' tourists to destinations. Experts say, locations and cultural performances in real precincts leave a lasting impression on the viewers more than anything else and induce them to go to such locations. The British Tourism Association (BTA) states that it is the screenplay and cinematography which adds to the beauty of a movie and projects a colorful image to the audience. It is not only the costumes in a Bond movie which attracts the audience but also the destination themes, settings, etc. which sink into the minds of the viewers and motivate them to go for the movie.

It is impossible to imagine a movie without a location. Tourism too, at its crux relies on locales. Therefore, it is most likely that films influence the audience when they watch exotic locations, scenic ambience, snowy landscapes, lush green backdrops, sky scrapers, cruises, and vibrant cultural symbols. Bollywood movies shot in scintillating European countries propel the enthusiasm and interests of Indian outbound tourists. Film Studios, Film Festivals and sets are also major pull factors in attracting tourists.

The silver screens have spread its wings to inspire the tourists by arousing their passion. Film tourism is indeed exciting and 
promising, resulting in cultural exchanges, creating new avenues of employment, and enhancing the lives of local communities. The future course of this special interest tourism phenomenon, though positively placed, needs to be meticulously promoted and systematically organized with innovative itineraries.

\section{Purpose and Need for the Study}

The purpose of this study is to examine the development process of Puducherry as a premier film tourism destination and how the image of 'Brand Puducherry' is enhanced by the movies shot in the Union Territory. The multitude of impacts owing to the depiction of the picturesque and idyllic locales of Puducherry in movies on tourist arrivals and branding is evaluated.

Movies are one of the most popular medium of entertainment in the present day. Most of the movies shot in Puducherry such as Life of Pi, Jism, Kaakha Kaakha, and Friends have become huge hits. The scenes highlighting Puducherry created an urge amongst tourists and film makers to visit the place and enjoy the stunning products and expressions. This study is directed at assessing what movies can do to 'Destination Puducherry'.

\section{Literature Review}

Film-induced tourism is defined as tourist visits to the destinations featured on television, video or cinema screen (Hudson \& Ritchie, 2006). When people are seeking sights seen on the screen, they are film-induced tourists (Busby \& Klug, 2001). For tourism destinations, movies not only provide short-term revenue but also long-term prosperity. It has been widely recognized in tourism promotional literature that destination image profoundly influences tourists' choice of destinations.

Gjorgievski and Malles Trpkova (2011) opine that film tourists are special interest tourists whose motivation for travel was filminduced. Film tourism destinations are exclusively connected to places, locations, events, and characters promoted on the cinema screen. Hudson (2008) in his snapshot on 'promoting destinations through film' argues that despite the growing awareness of the 
relationship between film and tourism, as well as the anecdotal application of film tourism in destination marketing, the impacts of film tourism still appear to be under-appreciated. Film tourism also includes film -studio theme parks and screening of special block-buster movies at amusement parks. A relatively recent phenomenon is film-festival tourism (Gupta, 2011).

Yet, a threat in these aspects is that the actual location may turn out to be different from what is being portrayed through advertisements or in films, resulting in dissatisfaction of tourists.

In the view of MacCannell (1976), "Media such as films enable the intangible attributes of tourism to be shown as tangible". Motion pictures have a powerful influence on the audience. They act as 'markers' that give both real and imagined meaning to a tourist attraction and are effective ways of enticing tourists to the locations they view in the movies. It is generally accepted that 'movieinduced tourism' relates to on-location tourism that follows the success of a movie made or set in a particular region (Beeton, 2005). Films have an effect on human behavior and very often they serve as an agent of social control and change (Slocum, 2000). This holds good in the case of tourist motivation and behavior as it helps in the development of a destination's identity and image. Films do provide immense exposure to tourist destinations, attractions, towns or regions (Tooke \& Baker, 1996). The positive correlation between film tourism and destination marketing has been established by researchers namely Riley, Baker, Tooke and Van Doren (1998). According to Ryan (1996), the relationship between fiction, dreams and tourism impacts has long been ratified. Similarly, Cohen (1986) identified 'media fiction' as tourism promotional tool. Prentice (1990) underscored the significance of images influencing individual's understanding and expectations when they are visiting the places portrayed in the movies. Impressing upon wide and diverse markets, film tourism offers something for everyone, just like the films themselves, and tourism organizations now use films as springboards for marketing campaigns, if the films are seen as appropriate for the destination (Hudson \& Ritchie, 2006). There is no doubt that films scale-up the visitor influx at their respective locations (Tooke \& Baker, 1996). In the words of Tetley (1997), "Filming not only provides short term 
employment and publicity for the chosen location but also long term tourism opportunities". One of the major economic benefits and factors of film tourism promotion is that visiting film locations can often be an all year, all-weather attraction, thus alleviating problems of seasonality (Beeton, 2004). The synergy between DMOs world over and film offices can result in a win-win situation. Cobb (1996) states that film offices in some states of America like Montana, Wisconsin, North and South Dakota are part of their state's tourism operations and are funded through their respective tourism departments. Tooke and Baker (1996) recommend that the movie producers themselves should consider approaching locations for financial investment or seek funding for their films.

\section{Objectives of the Study}

- To study the film tourism potential of Puducherry and its impacts on the dynamics of destination branding.

- To examine how destination image is affected by movies shot in Puducherry.

- To elucidate the opportunities and challenges as regards film tourism in Puducherry.

- To suggest ways and means for film-induced tourism development in Puducherry by formulating a model.

\section{Scope of the Study}

Of late, tourism marketing in Puducherry has experienced a paradigm shift. The multi -USP destination attracts completely different segments. This study conducted in the capital city of the Union Territory of Puducherry evaluates the trends and practices as regards film tourism. There is ample scope for such a study at the time when Puducherry is emerging as a world-class tourism destination witnessing significant growth in tourist arrivals and revenue receipts and the promoters are designing new propositions to lure tourists. The dimensions of film tourism in Puducherry have not been studied in-depth and this work attempts to fill this gap. 


\section{Research Methodology}

The present study is an exploratory one. This work ascertains the film tourism potential of Puducherry and analyses the various attributes and impacts that go into the making of "Brand Puducherry". Delphi Technique and Focus Group Interviews using structured questionnaires were employed to gather first hand insights from the experts, stakeholders, and tourism officials. The questions were framed based on the criteria developed for measuring the impact of film tourism in Puducherry. Surveys were also conducted with the staff of travel agencies and tour businesses and also the tourism offices in Puducherry. Opinions and view points were sought from 14 experts and practitioners. Content analysis has been carried out to draw inferences. It was also ascertained with a select group of respondents, sample size of fifty comprising domestic tourists, mostly first time visitors, whether they were inspired or influenced by the portrayals of Puducherry tourist spots in popular movies. The secondary data for the research has been collected from books, periodicals, journals, websites, social networking sites, and promotional literature.

\section{Tourism in Puducherry-Practices, Patterns, and Propositions}

Puducherry is a spectacular tourism destination with a progressive outlook. Tourists from all over the world are attracted towards Puducherry. A blend of spiritual aura and French colonial heritage, this amazing little town on the Coromandel Coast has a special ambience. A Union Territory of India, Puducherry comprises of four coastal regions, which are: Puducherry, Karaikal, Mahe and Yanam. Tourism in Puducherry is growing at a phenomenal rate, in fact, above the national average growth rate (Puducherry Tourism, Govt. of Puducherry, Arrival Statistics, 2012). The main contributing parameters for the development of Puducherry tourism sector are tourist inflow, revenue, and foreign exchange earnings. The French architecture and heritage and the stunning beaches and resorts have become important selling points. Puducherry dots a vital spot in the itineraries of tour operators across the globe and the growth in tourists' influx speaks volumes 8 
about its surge. Puducherry, which throbs with spiritual radiance, was frequented by the Romans during 200 B.C. Inbound tourism in Puducherry is robust and is regarded as the mainstay of its progress. The direct and indirect dependence of the people of the Union Territory on tourism businesses is evident from the significant contribution of revenue generated from varied tourism activities to the GDP of the Union Territory. Tourism accounts for one-fifth of the total GDP of Puducherry.

Puducherry is endowed with a wide range of fabulous tourism attractions that fascinate the tourists. Serenity is the hallmark of Puducherry and the competitiveness of the destination is attributed to the locale, hospitality establishments, transport networks, safety and security, and the accommodative spirit of the host community. To cap it all, the French have left behind an indelible legacy reflected in the art, architecture, cuisine, and heritage. Puducherry is now described as 'a state of mind' and offers unique experiences and events such as International Yoga Festival and Surfing Festival.

Puduchery Tourism has been striving hard to position the destination as an ultimate and overwhelming tourist centre by taking advantage of its French Connection, Aurobindo Ashram, and long quiet beaches. The Puducherry Shopping Festival has become a huge draw. A series of initiatives have been taken to build physical infrastructure and beautification of sites. In fact, the Government of Puducherry is modelling tourism development on the lines of Malaka in Malaysia as both the destinations have many similarities. The magnitude of tourism activities coupled with development of tourism infrastructure has created a conducive environment for entrepreneurship development.

The quintessence of Puducherry is that it is a small destination with the advantages of a big destination. With the diversity in tourism attractions, Puducherry has emerged as a remarkable tourism destination largely due to its strategic location, salubrious climate, and hospitable people. The need of the hour for Puducherry is to transform from a mass tourism destination to a class tourism destination by focusing on quality tourism development not on quantitative measurements.

Table 1: Classification of Major Tourism Attractions of Puducherry 


\begin{tabular}{|l|l|}
\hline \multicolumn{1}{|c|}{$\begin{array}{c}\text { Tourism } \\
\text { Attractions }\end{array}$} & $\begin{array}{l}\text { Products, Special Features, Activities, and } \\
\text { Propositions }\end{array}$ \\
\hline $\begin{array}{l}\text { Culture \& } \\
\text { Heritage }\end{array}$ & $\begin{array}{l}\text { French Heritage, Ashram, Cultural } \\
\text { Confluence, Arikamedu, Museums, } \\
\text { Cuisine, Handicrafts, Concerts, Indigenous } \\
\text { products. }\end{array}$ \\
\hline $\begin{array}{l}\text { Art \& } \\
\text { Architecture }\end{array}$ & $\begin{array}{l}\text { French colonial architecture, Churches, } \\
\text { Basilica, Tamil heritage buildings, } \\
\text { Boulevard. }\end{array}$ \\
\hline Fairs \& Festivals & $\begin{array}{l}\text { International Yoga Festival, International } \\
\text { Surfing Event, Veerampattinam Car } \\
\text { Festival, Bastille Day, Villianur Car } \\
\text { Festival }\end{array}$ \\
\hline $\begin{array}{l}\text { Leisure \& } \\
\text { Recreation }\end{array}$ & $\begin{array}{l}\text { Exotic beaches, resorts, Chunnambar lake, } \\
\text { Amusement park, Botanical Garden, } \\
\text { Wellness, Ousteri Lake, Sunday Market, } \\
\text { Multiplex, Golf Course. }\end{array}$ \\
\hline $\begin{array}{l}\text { Shopping \& } \\
\text { Souvenir }\end{array}$ & $\begin{array}{l}\text { Puducherry Shopping Festival, Boutique } \\
\text { Shops, Handmade Paper Products, } \\
\text { Antique Furniture, Incense, Pottery, Art } \\
\text { Galleries, Tattooing. }\end{array}$ \\
\hline MICE \& Events & $\begin{array}{l}\text { Petanque Tournament, Handball } \\
\text { Tournament, Vintage Car Rally, Bonjour } \\
\text { India, Fete De Puducherry. }\end{array}$ \\
\hline
\end{tabular}

\section{Film Tourism Potential of Puducherry vis-a-vis Destination Branding}

Puducherry is now being recognized as a hub for shooting films and the destination developers have realized the need for mooting film tourism industry in the Union Territory. With an everincreasing number of films being shot in the destination, Puducherry is fast becoming a film maker's paradise. Puducherry is now a favorite place of feature and advertisement filmmakers owing to picturesque locations, easy permits and low costs. Furthermore, the French architecture and rues (streets) with an old 10 
world charm portray Puducherry as a unique tourism centre. Apart from the long serene beaches, the boulevard areas, churches, heritage buildings, port area, East Coast Road (ECR), lakes, and ravines are also popular shooting spots in this coastal town. Not only Tamil movies but also Hindi, English, Malayalam and Telugu movies are shot in Puducherry.

In the words of Mathew Samuel, former Director of Tourism, Government of Puducherry, who was interviewed for the study: "The trends of branding Puducherry through film tourism can be looked at in two ways. Firstly, the film and advertisement crew may be greatly inspired through effective marketing communication to visit Puducherry as tourists. Secondly, they may be induced to stay here, capture the startling contours of Puducherry, and widely publicize the tourism spots through their movies. Thus, films serve as enormous vehicles to promote Puducherry as a tourism destination. The film makers must be motivated to project the beauty of the town and the beaches and encourage more and more people to visit it."

The concept of transforming Puducherry as an awesome location for film shooting has gained momentum owing to the outstanding depiction of Puducherry to the worldwide audience through the Oscar winning movie 'Life of $\mathrm{Pi}^{\prime}$. Ever since the movie turned a block buster and won Oscars, crew members pan India and overseas have landed in Puducherry to film the captivating locations. The destination planners see a great potential in promoting film tourism by capturing the beautiful promenade and other beaches, perpendicular streets, statues, palatial houses, the scenic botanical garden, colonial French structures, and exquisite churches, which may fetch more revenue to the government, local bodies, hotels and restaurants. Places of tourist importance such as Beach Road, East Coast Road (ECR), Bharathi Park, Botanical Garden, Ariyankuppam, Muthaliarpet, and the Chunnambar Boat House have been the favorite film shooting locations in Puducherry so far. A number of new spots have been added to the list, post screening of Life of $\mathrm{Pi}$, which was shot in at least 18 locations in Puducherry. According to a rough estimate, more than 350 short, feature, and advertising films were shot in Puducherry till now. Tour promoters are of the view that the success of films like Life of 
Pi, Varanam Ayiram, Jism, Kannathil Muthamittal, Minnale, Talaash, and Friends is definitely wooing film makers to Puducherry.

Recognizing the importance of cinema as a powerful tool for the development and promotion of various tourist destinations, India Tourism has launched the Land of Pi campaign laying stress on the locations featured in the movie, mainly Puducherry. The media for the campaign will be print, online, electronic and outdoor. According to this campaign, 'Land of $\mathrm{Pi}^{\prime}$ posters produced by Union Tourism Ministry will be displayed worldwide through the India Tourism offices overseas. These would also be put on the Incredible India website and the website of Puducherry Tourism. Special 'Land of $\mathrm{Pi}^{\prime}$ tours and walking trails will be organized for tourists visiting Puducherry. Short clips and virals of the tourist attractions in Puducherry, depicted in the film, are uploaded in YouTube and other social media platforms. 'Land of Pi' contests are also organized. A boat that hints at 'Life of $\mathrm{Pi}^{\prime}$ with a stuffed toy tiger will be permanently placed at two prominent locations in Puducherry to provide snapshot opportunities to tourists. T-shirts and caps branding 'Land of $\mathrm{Pi}^{\prime}$ will be produced and distributed. Online video games will be made part of the campaign. (The Hindu Daily, 2013). The campaign will be undertaken in French, German, Chinese, Spanish and Japanese. Road Shows for promoting Puducherry tourism will be organized in countries where the movie was well received.

A trend study through a time-series analysis on the movies shot in Puducherry and its influence on tourism reveals that films have boosted the image of the destination and the Union Territory thus has been able to brand for success. The brand pull is certainly strengthened especially through word-of-mouth publicity post screening of films. The finer aspects of Puducherry such as the rich tapestry of music, arts, crafts, spirituality, and heritage have been knitted to perfection as a brand identity, courtesy the film industry. Film tourism will go a long way in positioning Puducherry in key international tourism markets.

The depiction and communication of authentic attractions in films assumes profound significance. Brand, ideally, must be based on reality and Puducherry in consonance with this need has to reflect 12 
Anu Chandran R C The Nuanced Approaches in Destination Branding

its core strengths and personality. To be a famous destination brand Puducherry has to be portrayed as more than the sum of all products and manifestations.

\section{Data Analysis and Findings of Survey among Tourists}

Table 1: Depiction of Tourist Spots of Puducherry in Movies Influenced the Visit

\begin{tabular}{|l|l|l|}
\hline Trip Induced by Movies & Frequency & Percentage \\
\hline Agree & 33 & 66.0 \\
\hline Disagree & 17 & 34.0 \\
\hline Total & 50 & 100.0 \\
\hline
\end{tabular}

Mean - 1.34, Median - 1.00, Mode - 1, Std. deviation - 0.479, Variance - 0.229 , Range - 1

The result clearly indicates that the majority of tourists $(66 \%)$ subjected to survey were affirmative on films depicting the tourist spots of Puducherry playing a key part in their tour decision making. As far as the respondents who disagreed with the proposition- that constitute $34 \%$ - are concerned, various other factors such as spirituality and the curiosity to watch the historical reminders would have acted as the driving forces that prompted the visits.

Table 2: Post-Visit Feedback; Film Tourism Showcasing Puducherry can Impact Destination Branding

\begin{tabular}{|l|c|c|}
\hline $\begin{array}{c}\text { Film Tourism can impact Destination } \\
\text { Branding through the Creation of an Identity }\end{array}$ & Frequency & Percentage \\
\hline Strongly agree & 16 & 32.0 \\
\hline Agree & 26 & 52.0 \\
\hline Undecided & 8 & 16.0 \\
\hline Total & 50 & 100.0 \\
\hline
\end{tabular}

Mean - 1.84, Median - 2.00, Mode - 2, Std. deviation - 0.681, Variance - 0.464, Range - 2

While gathering the responses of tourists post visits on whether film-induced tourism showcasing the unique places of tourist importance can make an impact on branding the destination by 
reflecting the 'sense of place', an overwhelming majority (84\%) confirmed the statement and expressed optimism against the background of their impressions gained on Puducherry. Eight percent of the respondents could not make a decision.

\section{Content Analysis}

The content analysis is based on the interviews with experts and stakeholders of Puducherry Tourism, allied Industries, NGO's, and consultants on the objectives of film industry in the promotion of film tourism.

The objective of bringing film tourism in Puducherry is to promote the tourist places by showcasing it in lenses so that people get to see Puducherry in a better way through films. The sites shown in films may influence the tourists to visit Puducherry, to the places where the films were shot, based on how beautifully it was portrayed. The main aim of film tourism is destination marketing. The proposal for establishing a Film City in Puducherry is being considered. After the screening of Life of $\mathrm{Pi}$ and Talaash recently, the tourist arrivals improved tremendously. A conducive political and socio-cultural environment must be provided to the movie makers.

\section{On Sites for Shooting}

The film producers may like to know the sites, where the film shooting may be done. Therefore we show them the sites ideal for shooting and guide them on the modalities for obtaining permission.

\section{On Conservation}

The monuments / heritage buildings can obtain resources for conservation through film tourism as they get a fee from the film crew who also don the mantle of tourists. Film shooting offers incentive for the upkeep and preservation of monuments and heritage sites. 
Anu Chandran R C The Nuanced Approaches in Destination Branding

\section{On the Costs}

The government is charging moderately for a day's shooting which is very less compared to other states.

\section{On Promotion}

The road shows we initiate in tourist generating markets help in inviting film makers too. Exclusive film tourism brochures will also be printed. Film tourism is not pro-actively promoted by the government in Puducherry. Obtaining permission for shooting is a big hurdle. Subsidies may be offered to the producers as a means of encouraging them. The film fraternity must form a tie-up with the Tourism Department for a win-win situation. Film tourism helps Puducherry to position its spots and resources amongst all segments and target groups. The original culture of Puducherry should be transmitted through the movies.

\section{Inferences and Discussions}

The inferences from the Delphi Study were drawn on the basis of thirteen parameters. Content analysis has been undertaken and the salient aspects are featured below.

i. Objectives of promoting Puducherry as a film tourism haven

Film tourism promotion in Puducherry identifies the optimum marketing factors that encourage film tourists to visit destinations appearing in movies. Films will showcase Puducherry in a better light through the lens. The main achievement will be cost-effective marketing. Local businesses will also receive ample thrust.

ii. Getting film makers to Puducherry

Eminent film makers from the country and abroad may be invited for a familiarization trip. They must be offered wholesome facilities and subsidies.

iii. Promotions abroad

Film tourism is a niche tourism product. Special bodies / cells may be incepted to handle promotion abroad. Moreover, MoUs could 
also be signed with foreign countries. Innovative partnerships can do wonders. Puducherry can launch its own film festival like the Puducherry International Film Festival (PIFF). Road shows also will help a great deal.

iv. Strengths of Puducherry as a film location

Apart from the heritage, cultural, and natural attractions, easy access, close vicinity, good connectivity, and low cost of living are the key strengths for film tourism promotion.

\section{v. Weaknesses}

Lack of incentives for film makers is a big hurdle. Language barrier is also a dampener. Traffic congestion, overcrowding, inadequacies in civic maintenance, lack of public conveniences, and attractive open spaces negatively impact film tourism in the UT.

vi. Strategies to Succeed

In travel marts, Puducherry Tourism must consciously promote film tourism locales. Tourism promotional literature exclusively on film tourism may be released. Along with maintaining good physical evidence, new projects may also be set-up in Puducherry to lure movie makers.

\section{vii. Attracting film production teams}

Imageries hold the key when it comes to deciding a location for films. Puducherry must project its unique ambience. Film executives and location managers need to be made aware of this.

\section{viii. Film tourism and increase of tourist influx}

Films shot in Puducherry have enhanced the brand value of its tourist spots. They have become very famous and are talked about in various forums. According to the hoteliers in Puducherry, many people visit the destination after watching the movies. They also evinced keen interest in going to the places picturised. Film crews themselves turn out to be tourists during their breaks.

ix. Sites preferred 
Anu Chandran R C The Nuanced Approaches in Destination Branding

The key sites preferred for film tourism are the French and Tamil Quarters, Promenade beach, Botanical Garden, Bharathi Park, Auroville, resorts, and heritage buildings.

\section{x. Sites' identification}

There are several agencies in Puducherry which help film makers in identifying their requisite sites keeping the budget in view. Many film makers express interest to shoot on 'real' places. The Department of Tourism staff can act as location managers as and when required.

\section{xi. Obtaining permission}

To ease the formalities in getting permission for film shooting, a single window clearance system can be introduced. There should not be any waiting period for the film crew; lest they may change plan and go to the neighboring tourism centers.

\section{xii. Conservation of resources}

Film tourism can give fillip to heritage resource conservation. To project the monuments and heritage structures in a mind-blowing fashion in films, they have to be protected and maintained well.

xiii. Benefits to local community

Film tourism can bring about multiplier effects which can economically benefit the local people. Job creation is yet another benefit as lot of avenues will be opened-up.

\section{Major Market Segments}

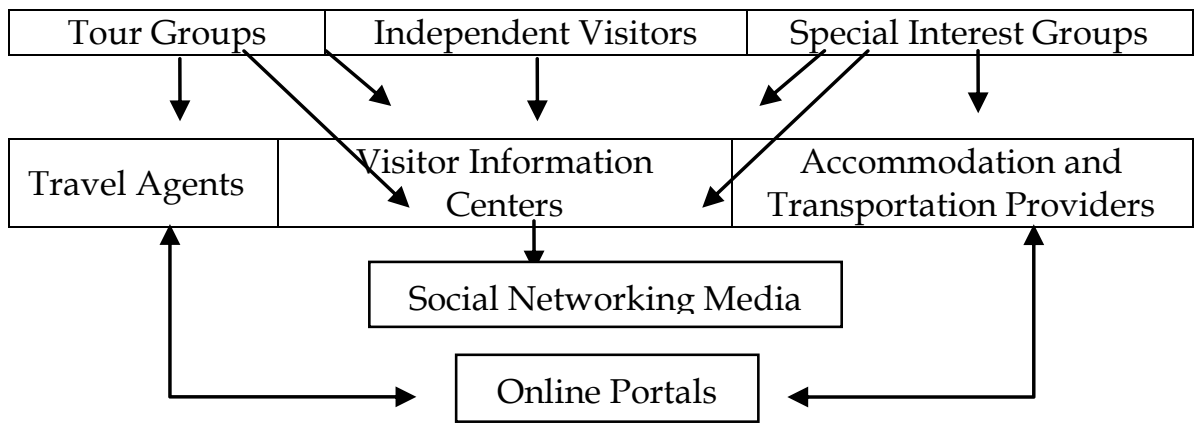

Fig. 1:Tourism Distribution Channel for the Promotion of Film Tourism in Puducherry 


\section{Major Findings}

The analysis indicated that movies can be used to enhance the brand image of destination Puducherry. It is a paradox that the Department of Tourism in Puducherry is yet to fully exploit the popularity of movies like the internationally renowned and Oscar winning Life of $\mathrm{Pi}$ shot in its tourism spots. The images sent out through the movies are sometimes not consistent with the offerings dished out in the destination. Authenticity is thus a very important consideration while portraying the tourism destinations. Shooting a movie in Puducherry is a low cost affair, but the formalities involving permissions, licenses, clearances, and sanctions pose a tough hurdle. Moreover, lack of amenities works against the active promotion of film tourism. A Film City project is on the anvil. Film tourism generates revenue for the preservation of cultural heritage of Puducherry. Without the support of local communities, film tourism cannot develop in the desired manner.

\section{Suggestions}

Internationally renowned film makers need to be invited to Puducherry to capture the stunning visuals in a unique ambience and such films will vouch for the charm of the destination. New sites must be identified and developed for shooting. Air connectivity has to be improved. Landing facilities for chartered flights must be in place which may add teeth to the initiatives. Puducherry tourism can establish a special cell for the promotion of film tourism. The film makers must be given some kind of concessions and subsidies as a measure of encouragement. Good Public Relations is a dire necessity in the realm of film tourism promotion. 
Anu Chandran R C The Nuanced Approaches in Destination Branding

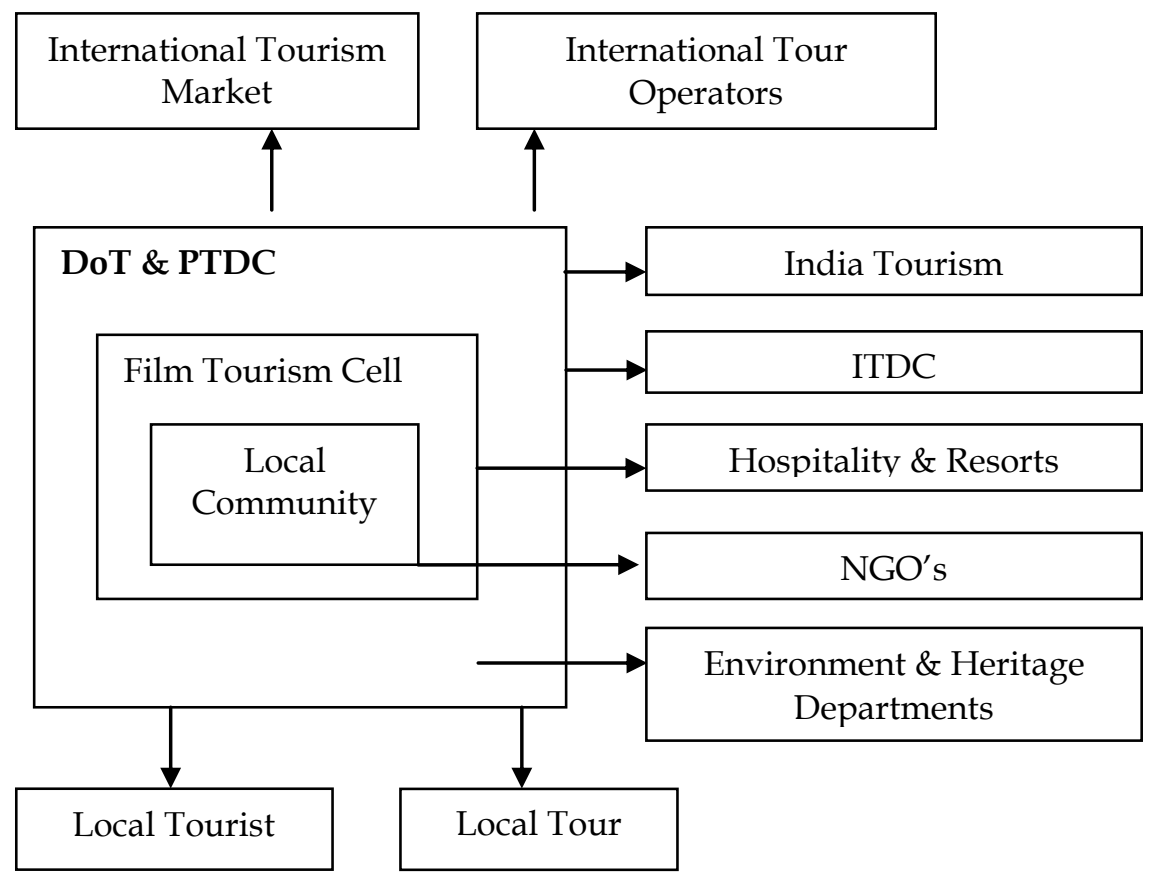

.2: Proposed Model for Film Tourism Development and Management in Puducherry

\section{Conclusion}

Puducherry is fast emerging as a premier film tourism destination especially after the success of the movie 'Life of $\mathrm{Pi}^{\prime}$ which was extensively shot in the destination. Now, it is time for the Union Territory of get the basics right in terms of improvement of civic infrastructure, protection of heritage manifests, increasing the number of quality rooms, and avoidance of congestion. Puducherry can have a bright future of being a hub for film tourism because of the mixed French and Tamil cultures, which is a rare combination and a USP for the destination. The entrepreneurs and investors in new projects such as eco-resorts must be encouraged to have facilities for film shooting inside their premises. Moreover, the film makers must be given a favorable environment, support, and also the amenities to complete their shooting within the schedule. Puducherry Tourism can take-up the promotion of successful movies- shot in the land- by arranging for its screening in various avenues. 


\section{References}

Beeton, S. (2004). Rural Tourism in Australia: Has the Gaze Altered? Tracking Rural Images through Film and Tourism Promotion. International Journal of Tourism Research, 6(3), 125135. doi: $10.1002 /$ jtr.479

Beeton, S. (2005). Film-induced tourism. Clevedon: Channel View Publications.

Beeton, S. (2005). Film - Induced Tourism (1 ${ }^{\text {st }}$ Edition). UK: Channel View.

Busby, G \& Klug J. (2001). Movie-induced tourism: The challenge of measurement and other issues. Journal of Vacation Marketing, 7(4), 316-332.doi:10.1177/135676670100700403

Cobb, K. (1996). Lights! Camera! Profits!. Fedgazette, 8 (2), 6-8.

Cohen, J. (1986). Promotion of overseas tourism through media fiction, in tourism services and marketing: Advances in theory and practice, in Proceedings of the Special Conference on Tourism Services (pp. 229-237). Cleveland, $\mathrm{OH}$.

Gupta, D. (2011). Tourism marketing. Delhi: Pearson.

Evans, M. (1997). Plugging into TV Tourism. Insights, pp. 35-38.

Mijalce, G \& Trpkova, S. (n.d.). Movie induced tourism: A new tourism phenomenon. UTMS Journal of Economics, 3(197-104. Retrieved from http://utmsjoe.mk/files/Vol. 3 No. 1/1-C3Gjorvievski.pdf

Simon, H. \& Ritchie, J R B. (2006). Film tourism and destination marketing: The case of Captain Corelli's Mandolin. Journal of Vacation Marketing. Sage 12 (3), 256-268.

Mehdudia, S. (2013, January 13). Life of Pi to inspire 'Land of Pi' campaign. The Hindu Daily, p. 5.

MacCannell, D. (1976). The Tourist: A New Theory of Leisure Class. New York: Shocken Books.

Prentice, R. (1996). Tourism as Experience; Tourists as Consumers. Edinburgh: Queen Margaret College.

Riley, R, Baker D \& Van Doren, C S. (1998). Movie Induced Tourism, Annals of Tourism Research, 25(4), 919-935. doi: 10.1016/S0160-7383(98)00045-0

Ryan, C. (1997). The Tourist Experience. London : Cassell.

Slocum, J D. (2000). Film Violence and Institutionalization of Cinema. Journal of Social Research, 67(3), 649-660. 
Anu Chandran R C The Nuanced Approaches in Destination Branding

Tooke, N, \& Baker, M. (1996). Seeing is believing: The effect of film on visitor numbers to screened locations. Tourism Management, 17 (2), 87-94. doi:10.1016/0261-5177(95)00111-5

Tourist Arrivals: Puducherry (n. d.). Retrieved June 1, 2014, from http://www.pondytourism.in/

UNWTO World Tourism Barometer. (2013.). Retrieved June 1, 2014, from mkt.unwto.org/barometer

WTTC-TSA, Press Release. (n.d.). Retrieved July 1, 2014, from WWw.wttc.org 